\section{Another vaccine enters the fray}

Tokyo

JAPAN'S Chemo-Sero-Therapeutic Research Institute (Kaketsuken) plans to export a newly developed recombinant hepatitis-B vaccine to South-East Asia and China where the virus is one of the main causes of cancer. The vaccine will compete with similar products made by US and European pharmaceutical companies. But the Japanese vaccine is unlikely to make significant inroads outside Japan until it is much cheaper.

The institute's plans to export the vaccine, will be finalized within the next six months, according to Satoru Tsutsui, manager and patent attorney for the institute's Kikuchi Laboratory in Kumamoto in Kyushu, Japan's southern island. Many problems, however, remain to be resolved over patent rights for the new vaccine.

Hepatitis B is a leading cause of cancer in the Far East. In Japan, several million people are carriers of the virus and each year more than 100,000 people are infected, about half of whom will develop liver cancer. In China and South-East Asia, at least one in ten are carriers.

Kaketsuken's vaccine was developed in collaboration with Professor Kenichi Matsubara of the Institute of Molecular and Cellular Biology of Osaka University with the support of an $¥ 830$-million ( $\$ 7$ million) grant awarded in 1984 by the Research and Development Corporation of Japan, an affiliate of the Science and Technology Agency (STA).

The vaccine is made of viral proteins mass-produced in a yeast host, a technique also used by the pharmaceutical companies Merck and SmithKline. Japan's Shionogi and Banyu pharmaceutical companies have received permission to import Merck's vaccine to Japan, and several other Japanese pharmaceutical companies are making similar arrangements. But Kaketsuken is the only Japanese organization which has developed and is producing and marketing its own recombinant vaccine.

STA and the institute have applied in Japan, the United States and Europe for patents for the recombinant plasmid used in production of the vaccine, and a US patent was recently issued. But Tsutsui admits that there is "probably" overlap with patents filed by other companies.

The market at stake is enormous. In Japan alone, Tsuitsui estimates that there is a need for about a million doses of the vaccine in the first year of production. This will tail off after a few years to about 50,000 doses a year for newborn babies once most adults are immunized.

David Swinbanks

\title{
Greenpeace's running battle with France now in Antarctica
}

Sydney

THE French government has locked horns again with the environmental group Greenpeace, this time over alleged violations of the Antarctic Treaty. The Greenpeace ship, MV Gondwana, arrived in the Antarctic last Friday to protest against the construction of a runway at the French Antarctic base, Dumont d'Urville. Early on Saturday morning, construction site personnel attempted forcibly to remove blockades set up by the protesters. Peter Wilkinson, expedition coordinator, said

\section{IMAGE UNAVAILABLE FOR COPYRIGHT REASONS}

French construction workers keeping Greenpeace supporters out of their survival hut $(A P)$.

that "the French construction men (were) not much better than hooligans looking for a fight". Work on the airstrip has ceased while the construction crew await orders from Paris

Greenpeace are protesting at the fact that, in the past six years, five islands have been flattened with explosives and the channels between the islands filled in. This has resulted in the blocking of the traditional migratory path of a colony of emperor penguins and the destruction of the breeding grounds of the Adélie penguin. According to a spokesperson for Greenpeace, Michael Bland, this constitutes a violation of the Antarctic Treaty.

Greenpeace claims that the runway is being built to provide the infrastructure for the future development of mineral exploitation. The Gondwana's protest coincides with a campaign to discourage Australia from ratifying an agreement allowing oil and mineral exploitation in the Antarctic. Greenpeace has accused Australia of complicity with the French.

The French expedition is using Hobart in Tasmania as a staging post for delivery of equipment and materials to Dumont d'Urville. "We have told the Australian government that this equipment is not for scientific use but they have chosen not to protest to the French", Bland said. The Federal Department of Environment in Canberra declined to comment.

Tania Ewing

\section{Shake-up for UK electronics industry}

\section{London}

THE latest move in the re-shaping of the European electronics industry could result in the take-over of Britain's largest electronics group, the General Electric Company (GEC), by an international consortium led by Plessey, the country's second largest electronics company. A firm bid, which will need to be in the region of $£ 7,000$ million, has not been made and the members of the consortium are not yet known, but it is though likely that it will include the British companies Plessey and STC, as well as Thomson, the state-owned French company, and General Electric and AT\&T of the United States.

The existence of the consortium was announced this week by Lazard Brothers, the merchant bank which is advising Metsun Limited, the company set up to make an offer on behalf of the consortium; the same bank is advising Plessey on its defence against the joint take-over bid by GEC and the West German company, Siemens. The announcement was greeted with speculation that it was an attempt to force a referral of the $£ 1,700$ million GECSiemens bid for Plessey to the Monopolies and Mergers Commission. GEC and Plessey are among the biggest suppliers to the Ministry of Defence, which is keen to maintain a competitive procurement policy. It is not clear how those behind either bid will assure the ministry that competition will not be lost nor how the diverse interests of all the companies thought to be behind the latest take-over bid would be combined.

British electronics companies are constantly criticized for their reluctance to invest sufficiently in research. The managing director of GEC, Lord Weinstock, has built up a $£ 1,500$ million cash mountain while excellent research in GEC laboratories lacks the investment needed to turn that research into marketable products. But it is feared that if foreign interests were to dominate a consortium that controlled the company, then much of the defence research, which is the driving force of Britain's electronics industry, could go abroad. Christine McGourty 